Book Reviews

Malveaux, Gregory F. (2016). Look Before Leaping: Risks, Liabilities, and Repair of Study Abroad in Higher Education. London: Rowman \& Littlefield. 234 pages.

\title{
Bill Frederick
}

Lodestone International

Gregory Malveaux, a professor and study abroad administrator at Montgomery College, has performed an excellent service for higher education study abroad. In his book Look Before Leaping, he weaves together logical arguments for improving health, safety, security and risk management practices. He incorporates lessons from higher education study abroad lawsuits with his analysis of some of the well and not so well known historical incidents. He makes his case drawing from academic papers, input from a dozen or so "experts", as well as his own experience as a program leader and administrator.

After reviewing some history of higher education study abroad, Malveaux introduces his own acronym "LARGEST": Liability And Risks in Global Education and Study Travel. He then dedicates a chapter to each of what he calls the LARGEST three: medical risks, sexual assault and supervisory neglect. Each chapter surveys a number of civil court cases presenting the story, the litigated issues and the risk management vulnerabilities of the school or program provider.

As "LARGEST" indicates, the author's focus is on legal liability and to that end there is an excellent examination of the wording and content of risk averting documents. The author provides nine sample waivers including the Malveaux Sample Recommended Waiver for Minimizing Risks and Liability in Study Abroad. What's missing from the discussion is any mention that civil court cases are generally tried under state laws and that those laws vary considerably from state to state. What might be an effective waiver in one state court may not be in another. Title IX and the Americans with Disabilities Acts are addressed. However, despite highlighting the need for participant medical and mental health histories, Malveaux does not discuss the Federal Education Right to Privacy Act and the Health Insurance Portability and Accountability Acts. Opportunities for transferring risk to insurance companies, to examining medical professionals and to mental health counselors are also not mentioned.

The last three chapters are each entitled "The Experts Advice: Best Practices" with each chapter addressing a subsection of the 23 areas that he and his advisors have identified as the critical risk management areas with corresponding guidance.

Malveaux frequently quotes the "expert opinions" of a group of twelve study abroad practitioners whom he interviewed for this work and to whom he attributes the highlighted best practices. He gives each a pseudonym without explaining the rationale for concealing their identities. However, despite citing a broad range of resources, there is a narrowness of perspective that detracts from his being wholly successful. Variability of program models is not addressed and some prescriptive advice, e.g. ratio of staff to students, is not applicable to all models. Malveaux in various 
instances cites the need for good in-country information but appears to advocate complete reliance on traditional resources, i.e. the U.S. State Department, the Centers for Disease Control, travel agents and in-country providers. There is no indication that he is aware of the very sophisticated external networks of expertise that arguably have become the norm for higher education study abroad. Insurance, security and information technology companies have mushroomed over the past dozen years providing a range of services including evacuation and repatriation, medical oversight, medical resource vetting, security intelligence distributed to administrators and trip leaders in real time, student tracking, crisis communications assistance, etc.

"Supervisory neglect", which is argued to be a contributing factor in some court cases but is not an event in and of itself, is listed as one of the three LARGEST. However, other more prominent contributing factors are largely omitted. Mental health is mentioned only in connection to a single case and alcohol consumption is not addressed in any substantive way. Recently developed modalities for managing mental health issues are also not explored. It may be the case that plaintiffs' lawyers do not often cite their clients' subjective contributions to health, safety and security events, but Dr. Malveaux purports to be offering comprehensive risk reduction strategies including a suggestion to provide self-defence training to students and counting trial and error as a best practice.

In the first chapter Dr. Malveaux states: "As far as a couple of decades ago, courts began to hold study abroad programs and their institutions more accountable for damages than in previous years" (p. 7). That statement is true insofar as the first legal cases cited by Malveaux, where the defending institutions were found liable, are from 1996. It is implied that this represents the beginning of a trend. However, 15 out of the 17 total cases and other notable complaints cited for this study are from 2004 or earlier and the institutions were not always held to be at fault. Additionally, there have been two recent court cases (in 2015 and 2017) that appear to contradict the idea that institutions are increasingly held responsible for student injury and illness. (Boisson v. Arizona Board et. al and Downes v. Oglethorpe University, Inc. 2017).

The best practices presented here do not break new ground. Most have been previously addressed in either NAFSA's Responsible Study Abroad: Good Practices for Study Abroad or the Forum on Education Abroad's Standards of Best Practice. The increasing professionalism of the field that has accompanied the evolution of information and communication technology is under-recognized in Look Before Leaping. However Dr. Malveaux has made an excellent contribution to health, safety, security and risk management in study abroad. His mapping of much of the hard experience of the field through court cases and other health, safety and security events provides a uniquely grounded historical perspective. To fully understand study abroad risk management, one needs to understand where the field once was and the events that brought it to where it is today. Look Before Leaping is essential reading both for those who wish to understand health, safety and security in study abroad as well as for those responsible for risk management. Program managers would do well to examine their institution's health, safety, security and risk management strategies as they read through this volume. 
Raby, Rosalind Latiner and Valeau, Edward J., eds. (2016). International Education at Community Colleges: Themes, Practices, and Case Studies. New York: Palgrave Macmillan. 350 pages.

Editors' Note: International Education at Community Colleges: Themes, Practices, and Case Studies by Rosalind Latiner Raby and Edward J. Valeau is a work that covers a broad range of topics related to international education, as its title implies. We are fortunate to have received two reviews-one from Melissa Whatley, whose focus is specifically on study abroad and student access; and the other from Martin Tillman who, drawing on his past work on internationalization strategies at a community college, addresses the remaining topics covered in the volume. While it is not typical practice for Frontiers to present two reviews of the same work, we felt that the reviews complement each other and should be read together.

\section{Melissa Whatley}

University of Georgia

\section{Community Colleges: A Resource for Diversification in U.S. Study Abroad}

The Institute of International Education's annual Open Doors report consistently indicates that participation in study abroad is increasing. Indeed, over the past two decades, the number of U.S. students studying abroad has more than tripled (IIE, 2017). Unfortunately, this growth has not resulted in proportional increases in participation among underrepresented student groups, such as racial minority groups, first-generation college students, and students from low-income backgrounds (Andriano, 2010; Salisbury, Paulsen, \& Pascarella, 2011; Simon \& Ainsworth, 2012). Given the prominence of the community college sector in the initial college education of many underrepresented student groups (González Canché, 2014), two-year institutions may represent an untapped resource in efforts to democratize U.S. study abroad. This volume presents a rich collection of theoretical and empirical work that examines issues surrounding not only study abroad, but international education generally, at community colleges. This review focuses on chapters that deal specifically with study abroad, as opposed to other topics in international education, such as international students or faculty development abroad.

\section{Summary}

The first chapter in this book that considers study abroad, "Study Abroad as SelfAuthorship: Globalization and Reconceptualizing College and Career Readiness," focuses on the community college's role in career preparation. It presents global literacy as a skill that these institutions must impart to their students. The chapter's authors view study abroad as a catalyst for self-authorship, the internal capacity to determine one's own beliefs, identity, and social relations, which in turn provides students with necessary skills for professional interaction in a globalized workplace. A second chapter, "Microaggressions and Intersectionality in the Experiences of Black Women Studying Abroad Through Community Colleges: Implications for Practice," highlights the 
unique opportunity that community colleges have to increase quality in study abroad for underrepresented students. In an analysis of semi-structured interviews with Black women who studied abroad through community colleges, the author sought to identify practices that may serve to improve education abroad for underrepresented student populations. Findings highlighted the discomfort that students felt in being the only Black student in a group, and point to the important role that peers play in providing comfort and support for their minority counterparts. Importantly, while all participants experienced some sort of microaggression while abroad, no student identified race or racism as themes covered in their pre-departure orientations sessions. This finding highlights an actionable agenda item for study abroad administrators and directors not only at community colleges, but at all institutions interested in the quality of the abroad experiences of underrepresented racial minority students.

Three additional chapters focus on issues surrounding access to education abroad. The first, "The Texas/Czech Republic International Connection: A Reciprocal Exchange of Faculty and Students," presents a case study of partnering institutions. In reviewing the history of this exchange, the author found a central role for upper-level administration in maintaining and growing the program. While faculty struggled to balance the program's administration with other responsibilities, the college's president was able to create and maintain program structure. A second chapter, entitled "Innovative Approaches to Study Abroad at Harper College and Fox Valley Technical College," presents a comparative case study that highlights the unique needs of community college students when considering study abroad. At Harper College, an initial focus on faculty as the target for study abroad participation has been key in that they return from abroad better able to internationalize their courses, subsequently inspiring students to study abroad. At Fox Valley Technical College, creation of affordable short-term abroad experiences that incorporate hands-on learning has been key to increasing study abroad participation. In an additional chapter, "Creating and Enhancing a Global Consciousness among Ethnic Minority Students in Community Colleges," authors highlight five high-minority community college districts that have demonstrated success in instituting study abroad. Overall, these successful programs benefitted from mention of global awareness in their institutions' mission statements and administrative support from at least one full-time director. Offices were proactive in helping students apply for financial aid and provided extensive pre-abroad preparation sessions. Targeted recruitment practices increased the number of minority students participating in study abroad, and alternative course designs and the integration of vocational credits ensured that students could fulfill degree requirements abroad.

Two final chapters concern themselves with study abroad outcomes. In "Community College Study Abroad and Implications for Student Success: Comparing California and New Jersey Community Colleges," researchers consider whether student participation in study abroad is associated with increased markers of student success. Using longitudinal data, findings indicated that study abroad participants completed transferable English and Math courses at a higher rate, completed more transferrable credits, were more likely to transfer to a four-year institution, completed their degrees at a higher rate, and exhibited higher retention rates. Finally, "Transformative Learning through Education Abroad: A Case Study of a Community College Program" presents students' descriptions of their experiences during a two-week-long program in Peru, the impact of their biographies on these experiences, and the influence of programmatic features on students' perceptions of study abroad. Findings indicated that students struggled to 
identify exactly what elements of study abroad produced their learning and highlighted a perceived lack of time to process the study abroad experience. The author concludes that while more time spent abroad may be desirable in an ideal scenario, community college students are often unable to participate in long-term programs. As such, focus should be placed not on recruiting students to longer-term programs, but rather on designing short-term programs as effectively as possible. While community college students may be more likely to have limited time to devote to study abroad compared to their four-year counterparts, practitioners and decision-makers at all institutions should consider the role of well-designed short-term abroad programs in opening access to study abroad to underserved student populations.

\section{Strengths of the Book}

The chapters just summarized exhibit several strengths. The first relates to the multiple theoretical perspectives that the authors employ, which serve to highlight different aspects of community college study abroad. For example, the conceptualization of study abroad as a catalyst for self-authorship provides a link between the career preparation role of community colleges and education abroad, while organizational theory provides insight into the ways in which study abroad can be structurally incorporated into community colleges. An additional strength of these chapters is that, taken together, they provide an overview of issues in study abroad that may be unique to or more prevalent among community college students. For example, these chapters highlight specific needs of community college students that may inform study abroad program design, such as the need to balance family responsibilities and school, and call attention to outcomes of study abroad, such as transfer to the four-year sector, that are prevalent among community college students. A third strength is that authors provide considerable attention to directions for future research on study abroad at community colleges, highlighting many empirical needs in this line of inquiry. Although study abroad at community colleges presents a prime opportunity for the diversification of U.S. study abroad, research concerned with education abroad remains focused on students attending four-year institutions.

\section{Future Research}

As just mentioned, future research on community college study abroad is needed to expand on the research presented in this edited volume. First, the case study methodology employed in the majority of these studies, while allowing for valuable, in-depth explorations of study abroad at one or a few institutions, is limited in that findings may be applicable only in very specific institutional contexts. Given considerable variation in the organizational features of community colleges, future research that considers a wider variety of institutions when collecting data is needed for more generalizable findings. Second, in examining the outcomes of community college study abroad, research is needed to account for the possibility of self-selection bias among study participants. That is, study abroad participants and non-participants differ from one another in systematic ways that likely relate to outcomes such as persistence and academic achievement (e.g., Luo \& Jamieson-Drake, 2015; Salisbury, Umbach, Paulsen, \& Pascarella, 2009; Stroud, 2010). The implementation of quasi-experimental techniques, such as propensity score modeling, to account for this lack of equivalence will provide more robust results concerning the benefits of study abroad participation for community college students. 


\section{Conclusion}

As noted in the introduction to this review, community colleges represent a mostly untapped resource for the diversification and democratization of U.S. study abroad. As just noted, directions for future research on community college study abroad abound. Such research would be greatly facilitated by the availability of data on the study abroad patterns and choices of community college students and the increased collaboration between administrators and other informationkeepers at community colleges and the researcher community. This sector of higher education has great potential as a primary site for addressing issues of access and equity in international education in the United States in the context of an increasingly diverse student body. The growing diversity of the U.S. student population only serves to underscore the importance of including all students in study abroad opportunities. While the chapters presented in this edited volume focus specifically on community colleges, the themes and ideas that they present are applicable beyond this specific sector of U.S. higher education. Many four-year institutions serve student populations that share many characteristics with community college students. In this sense, the contents of this volume are useful for all who are interested in providing study abroad opportunities to underserved populations.

\section{References}

Andriano, B. R. (2010). Study abroad participation and engagement practices of first-generation undergraduate students. Unpublished doctoral dissertation, The George Washington University.

González Canché, M. S. (2014). Is the community college a less expensive path toward a bachelor's degree? Public 2- and 4-year colleges' impact on loan debt. The Journal of Higher Education, 85, 723-759.

Institute of International Education. (2017). "Profile of U.S. Study Abroad Students, 2005/062015/16." Open Doors Report on International Educational Exchange. Retrieved from http://www.iie.org/opendoors

Luo, J., \& Jamieson-Drake, D. (2015). Predictors of study abroad intent, participation, and college outcomes. Research in higher education, 56(1), 29-56.

Salisbury, M. H., Paulsen, M. B., \& Pascarella, E. T. (2011). Why do all the study abroad students look alike? Applying an integrated student choice model to explore differences in the factors that influence white and minority students' intent to study abroad. Research in Higher Education, 52(2), 123-150.

Salisbury, M. H., Umbach, P. D., Paulsen, M. B., \& Pascarella, E. T. (2009). Going global: Understanding the choice process of the intent to study abroad. Research in Higher Education, 50(2), 119-143.

Simon, J., \& Ainsworth, J. W. (2012). Race and socioeconomic status differences in study abroad participation: The role of habitus, social networks, and cultural capital. International Scholarly Research Network, 2012, 1-21.

Stroud, A. H. (2010). Who plans (not) to study abroad? An examination of US student intent. Journal of Studies in International Education, 14, 491-507. 


\title{
Martin Tillman
}

\author{
Johns Hopkins University Paul Nitze School of Advanced International Studies (retired)
}

The national dialogue about the value of international education in an era of far-reaching globalization, and the discussion of how to prepare global-ready graduates, has not usually referenced two-year institutions. This despite the fact that community colleges enroll more than $50 \%$ of all first-generation and minority students in the nation. The impact of growing numbers of international students - even in small numbers - on these campuses also has the potential to alter the perception of the wider world both on campus and in the local community. However, as Raby and Valeau point out, "There is a special challenge for US community colleges to move from celebration of singular programs that make internationalization available to only a few students to sustainable change that influences the entire college community (p. 5)." The importance of this volume is self-evident at a time when the nation is grappling with a political culture that has turned the nation inward, while, at the same time, major international education organizations - NAFSA, IIE and AAC\&U - are pushing forward to widen opportunities for more students to study abroad (the IIE Generation Study Abroad initiative, begun in 2015, seeks to double the number of students studying abroad by 2020, https://www.iie.org/Programs/Generation-Study-Abroad/About ). Twenty-five of the current roster of "partners" in this national initiative are community colleges.

The uphill fight of community college leaders to internationalize their institutions is thoroughly chronicled in the early section of the book. Valeau and Raby reflect on the tension between the historic "core" mission of the community college to focus on needs of students drawn largely from their local community, and the effort to introduce a global perspective either in the curriculum or via international programs (pp. 10-15). They state: "Marginalization of community college international education is directly linked to a conceptual and developmental pattern that supports singular programming rather than holistic integration (p. 14). As they see it, a persistent false assumption maintains a community college cannot both aspire to internationalize the curriculum and develop international programs while also "serving the local community" (p. 10). As a counterpoint, the coauthors point out that the first president of the American Association of Junior and Community Colleges, Edmund Gleazer, stated in 1976, that “...we believe that a fair share of time and attention should be given to the international dimension ... without neglect to the domestic scene...” (p. 11). Unfortunately, more than four decades later, the data cited in this volume (although three to five years old) demonstrates that community colleges have a long way to go to measurably alter the landscape of international educational opportunities for their students. For example, a 2011 survey of 239 of the 1,200-community colleges, conducted by the American Council on Education, found that less than $25 \%$ had an internationalization plan (p. 2).

The book is divided into two parts: in the first section Raby and Valeau provide a detailed introduction to the complex history and uneven success surrounding internationalization of community colleges. They point out that the original mission of the community college, as far back as 1947, dictated they educate students "to produce an international citizenry" (p. 11). But, they discuss the strong community and institutional forces which have, over the decades, kept community colleges from realizing this globalist agenda and resulted in an international agenda becoming, in policy and practical terms, only "optional." Other chapters offer excellent literature reviews and 
discussions of varying approaches to internationalize campuses, develop professional development opportunities for faculty and effectively manage the growing number of international students on campuses. These accounts provide useful models of best practice and innovation for faculty and administrators at colleges exploring expansion of their international initiatives.

Bista (pp. 23-27) examines the role of foreign-born faculty and U.S.-born with international experience, in bringing an international perspective to both the classroom and off-campus programming at two targeted community colleges. He states, "there is limited literature on the work and scholarship of foreign-born faculty at community colleges (p. 26). Given the relatively small number of colleges with internationalization plans, understanding the positive role played by foreign-born faculty is of great consequence. They offer the campus and community a window on the wider world and cross-cultural sensitivity of value in supporting international students. They are more likely to champion the expansion of international programs on their campuses. Community Colleges for International Development (CCID), founded in 1976, has been a singular success in building international partnerships for study abroad and faculty training and development; there are now 26 member institutions. Treat's chapter (pp. 39-55) introduces a model mentoring experience on U.S. campuses for 26 faculty and administrators from Egypt through a partnership agreement with the Department of State Bureau of Educational and Cultural Affairs. While not unusual at fouryear institutions, this examination of the successes and limitations of this type of CCID initiative fills "the gap in the literature by providing an increased understanding of mentoring of international administrators and educators."

Other chapters discuss important approaches to enhance student learning: the role of the community college in assisting international students adapt to American culture and the norms of our academic system (Hagedorn, Pei, Yan \& Hollis, Davis); a model for "appreciative" international student advising (Zhang); the need to better inform international students of Title IX regulations; two chapters on study abroad focus on the persistent fact that study abroad has remained an experience largely open to white students and excluding the preponderance of minorities attending community colleges (Zamani-Gallaher, Leon, Lang \& Willis); a model for quantifying the variables which represent institutional internationalization (Bissonette \& Woodin); and lastly, a critical discussion of a model for measuring the type of leadership skills and background which provides a profile of existing community college international education leaders (Valeau and Raby).

The second section of the book presents twelve diverse case and research studies outlining varied models for design of education abroad programs, curricula innovation, international campus linkages, and holistic campus internationalization. Cases cover best practices led by faculty and senior administrators illustrating the opportunities and challenges facing institutions committed to preparing global-ready graduates. The first study, "Building a World-Class College: Creating a Global Community at Pima Community College" (Castro-Salazar, Merriam-Castro and López, pp. 175-188), reflects the stark nativist thinking confronting "global-minded" administrators supporting internationalization of this large institution (55,000 students) in Arizona. They outline efforts to push ahead with their plans despite strong anti-immigration sentiment in what they euphemistically refer to as an "ambivalent local populace." Rodríguez (pp. 223-236) outlines her innovative development of e-portfolios at Santa Fe College in Florida to align this curricula plan with the college's International Studies Certificate. The case of building a Global Learning Certificate via a 
collaborative initiative between Indiana University and the state's community college system (30 campuses in 14 regions) illustrates the promise and pitfalls of internationalization on such a large scale in a state (Cierniak and Ruddy, pp. 247-262). Despite a highly structured and well thought out action plan, agreement on strategy and goals, with dedicated staff and faculty committed to this effort, uneven buy-in from individual campus administrators and faculty led to difficulty in the first year of the plan's implementation.

This volume lays out a compelling case for internationalizing the curriculum and co-curricular programs for community college students in the United States. In his conclusion, Valeau asks, "...why internationalization at US community colleges is not widely established and institutionalized." He alludes to part of the problem, which is that data about internationalization, annually collected by the Institute of International Education, is received from only $1 / 3$ of all community colleges in the nation (p. 337). Valeau also asserts that the process of campus internationalization will not be more widely implemented as long as Boards, Presidents and faculty do not become champions on campus and in the local community. He questions campus leaders "whose ill-conceived reasoning is that dollars for international education distracts from the colleges' mission." In the country's current charged political culture, champions of international education are also pushing uphill against the prevailing mantra of "America first" in the halls of their state legislatures.

I hope this volume is widely read and that the insights and lessons gleaned from the campus cases serve as a catalyst for new innovative initiatives at a broader cross-section of US community colleges seeking to graduate global-ready students. These students deserve the same opportunities and advantages to develop 21st century skills and competencies, gained through well-designed international programs, as is available to students at four-year colleges and universities. Closing this opportunity gap, in my judgement, is critical if the nation is to keep up with the demands globalization places upon the workforce at home and abroad. 